\title{
Perceptions on Justice, the Judiciary and Democracy*
}

\author{
Fernando Filgueiras \\ Department of Political Science, Federal University \\ of Minas Gerais (UFMG), Brazil
}

The reliance on courts for addressing public policy questions and political controversies is a central phenomenon in contemporary democracies. The judicialization of politics is the result of a shift in core issues regarding democratic legitimacy, both in the sphere of institution building as well as political culture. Social justice arose as a central variable in the legitimacy of democracies, becoming vital in establishing support towards democratic political systems. This article explores the relation between perceptions on justice, judicialization of politics and how the agency of judicial institutions impacts dissatisfaction with democracy. Based on a survey carried out in the metropolitan regions of Belo Horizonte, Goiânia, Porto Alegre and Recife, it is argued that the discontent towards political institutions in Brazil does not justify the ongoing judicialization process since the perceptions on inequalities place the Judiciary within the citizens' critical stance towards institutions. Just like other representative institutions, the Judiciary has not been able to mitigate the perceptions on inequalities and the ineffectiveness of the empire of law, being therefore unable to provide a satisfactory performance in regards to the normative ends of contemporary notions of democratic legitimacy and citizenship.

Keywords: Perception of justice; distrust; judicialization; democracy

\section{Introduction}

$\mathrm{T}$ wo phenomena converge in Western democracies. On the one hand, Western democracies have lived with a permanence of distrust towards political institutions, leading to transformation processes in democratic legitimacy. On the other hand,

* The data necessary to reproduce numerical results can be found in http://bpsr.org.br/files/ arquivos/Banco_Dados_Filgueiras.sav 
Western democracies have provided institutional changes derived from a displacement of democratic legitimacy, many times supposedly nurtured by distrust in political institutions. The convergence of these two phenomena entails transformations in political representation, and in particular, it allows for the strengthening of counter-majoritarian institutions. These institutions are legitimized to the extent that its justification is set upon the argument that representational legitimacy does not depend exclusively on the electoral process. Consolidated democracies have undergone through transformations in political representation, which are driven by critical citizens and new forms of political participation by civil society, be these conventional or non-conventional forms (Norris, 2011).

The presence of critical citizens creates an ambivalent process in contemporary democracies. On the one hand, citizens endorse the normative values of democratic institutions and thus express satisfaction with the regime, and yet, distrust political institutions due to the freedom of information and the available cognitive conditions for regime evaluation. In turn, the presence of these critical citizens infers new ways of participation by means of social movements and new demands, especially in terms of social justice (Norris, 2011). In this sense, the democratic deficit occurs when "in many countries today, satisfaction with the performance of democracy diverges from public aspirations" (Norris, 2011: 4).

The Brazilian democratic regime, due to its transition process and institutional construction by means of the 1988 Constitution, strengthened these two processes within the State's normative organization and within the scope of political culture. Brazilian democratization occasioned in an interaction between political culture and institutional changes that have changed the panorama for democracy. That is, as in many consolidated democracies, as soon as Brazil attained its democratic transition it began to live with a normative and institutional convergence within its public sphere. And indeed, several empirical researches have revealed the aggravation of distrust in institutions in Brazil as well as the strengthening of judicial institutions (Moisés and Carneiro, 2008; Werneck Vianna et al., 2007). The dissatisfaction with the performance of institutions, conveyed by the presence of distrust, stems from a combination of aspirations for unaccomplished justice. The underperformance of political institutions and the presence of distrust led to the strengthening of counter-majoritarian institutions, particularly in the case of the Judiciary. The judgment of the "mensalão" case carried out by the Federal Supreme Court (STF), the judgment of direct actions of unconstitutionality (ADI's) and changes in the electoral and party system by the Superior Electoral Court (TSE) positioned the Judiciary in the center of a public opinion debate.

The growing judicialization of politics in Brazil stems from a series of institutional changes. This judicialization process holds a component of interaction between political 
culture and institutional change in which the Brazilian society sees the judiciary system as a space for the achievement of justice and citizenship. In this sense, a field of investigation opens up, relating perceptions on justice with the workings of institutions and democratic political culture.

The main goal of this article is to investigate the impact of the perceptions on justice with the dissatisfaction towards the democratic regime in Brazil and its relation with the theme of distrust in institutions. We argue that the discontent towards political institutions does not justify the ongoing judicialization process in Brazil since the perception regarding inequalities - of a substantial and procedural nature - places the Judiciary within the citizens' criticism towards institutions. Much like other representative institutions, the Judiciary has not been able to mitigate the perceptions on inequalities and the ineffectiveness of the rule of law, being therefore unable to have a satisfactory performance in regards to the normative ends of political institutions.

In the first section we deal with the issue of distrust in contemporary democracies and the arguments regarding its relation to the process of corrosion of democratic values. In the second section we deal with the relation between distrust and the empowerment of judicial institutions, observing the convergence among both of them as well as the consequent analytical possibilities. The third section deals with the Brazilian case, focusing on institutional changes within the Judiciary Power triggered by the promulgation of the 1988 Constitution. Finally, in the fourth section we present the research methodology and empirical findings from a survey on justice and the Judiciary in Brazil, carried out in the metropolitan regions of Belo Horizonte, Goiânia, Porto Alegre and Recife.

\section{Trust in Institutions and Democracy Displacements}

Generally speaking, Western democracies have been faced with an enigma: how to explain the growing dissatisfaction of citizens and their distrust towards democratic institutions and, at the same time, the support that these same citizens express towards the normative values of democracy? The issue of distrust and discontent towards political institutions has been shown to be a contemporary problem for democracy, taking into account a context of systemic changes and the emergence of new modes for mobilization and social participation. Ever since the work of Robert Putnam the theme has gained theoretical and analytical strength among democracy scholars. The author pointed out that distrust would be an element that places the legitimacy of democracy at risk as well as an expression of an authoritarian vestige (Putnam, 1993).

Luhmann observes that trust is a structuring element for social action. Insofar as modernity established a systemic and differentiated organization, centered on functions 
and objectives, superimposed on the traditional aspects of collective life, trust presents itself as a structuring element in accordance with the management of social expectations as carried out by highly differentiated institutions, no longer legitimized by traditional communitarian values, but instead, by a procedural conception. Social systems are legitimized by means of procedural rules and the social belief derived from these rules. Trust, in this sense, does not only involve individuals and their relations, but also society's systemic apparatus, grounded on abstract and functional institutions. Trust is an evaluative measure for public opinion concerning the institutions' fulfillment of their fundamental procedures, which in turn legitimize them and ensure their authority. According to Luhmann trust represents a belief regarding the working of institutions and their capacity to coordinate social expectations. Trust, in this sense, is fundamental to solidify a background belief able to maintain the workings of social systems (Luhmann, 1996).

This perspective of trust aims to mobilize the institutions' ethic and normative resources, especially for political institutions. Contrary to a perspective based on an idea that trust is centered on inter-personal relationships in which its inexistence calls sociability itself into question, the perspective of trust in institutions is based on the evaluation and judgment as carried out by public opinion. For Hardin, the inexistence of trust in institutions derives from the limited information available to individuals regarding politics. Distrust is a symptom of information asymmetry and the sparse cognitive resources available to public opinion (Hardin, 1999). On the other hand, Claus Offe argues that distrust results from the incoherence of institutions relative to their normative resources (Offe, 1999). Trust in institutions presumes that society is aware of their basic norms and their permanent functions in view of the normative values and purposes that surround them. To this sense, values such as probity, impartiality, virtues, and rights, organize institutions' normative ends and generate, at the level of society, normative expectations. Trust occurs when the citizens' experience with institutions is coherent with their expectations concerning the values and norms that surround them (Filgueiras, 2008).

The empirical research on trust has shown that consolidated democracies undergo common processes which combine distrust in institutions and adherence to democracy. For Inglehart and Welzel (2005), distrust towards democratic institutions creates hardships towards the legitimation of democracy. However, a large portion of the specialized literature considers that distrust is an expression of the citizens' critical attitude against the workings of the political system. In consolidated democracies, increasing cognitive qualification leads to better informed social segments, which in turn are more critical to the workings of the political system (Klingemann and Fuchs, 1995; Norris, 1999; Pharr and Putnam, 2000). On the other hand, for democracies still in consolidation, such as the case of Asia, Eastern Europe and Latin America, such distrust jeopardizes the 
government's capacity to coordinate society and to establish social cooperation (Newton, 1999). Furthermore, distrust towards political institutions does not allow for the consolidation of a democratic political culture grounded on these institutions' ability in building their normative justification (Dalton, 1999; Levi, 1998).

Regardless of the perspective by which one deals with the theme of distrust, the fact remains that it has promoted changes in practices within democracies. This collective malaise towards political institutions has led to an increasingly stronger presence of institutions grounded on indirect representation, particularly by the establishment of surveillance and vigilance institutions, and new actors who do not derive their authority from popular will, but from their capacity to modify the exercise of political power and to establish control over it (Rosanvallon, 2006). A political discourse fed by issues such as social injustice and corruption fortifies institutions grounded on surveillance, denouncements, and investigation, of which its legitimacy derives from presenting themselves as representatives of the public interest and not from electoral processes. Institutions such as the Public Prosecutor, the Judiciary, auditing or administrative control institutions, and the media, present themselves as new actors in the democratic political scene, and their legitimacy derives from their distance from representative institutions and interest groups. Transparency then comes to be an ethical resource - be it by the actions of these institutions or by the presence of an informational society - derived from the malfunctioning of democratic institutions (Filgueiras, 2011). According to Rosanvallon (2006), such process corrodes the institutionalization of political parties, electoral systems, governments and parliaments, and strengthens institutions that do not derive their legitimacy from popular sovereignty, but instead, from their capacity to establish surveillance and to distance themselves from politics itself.

As a result, counter-democratic institutions arise in order to correct representational flaws and the performance of representative democracy. Distrust nourishes processes such as judicialization of politics and the presence of bureaucratic institutions within the representational process (Rosanvallon, 2006). Distrust, therefore, promotes the displacement of legitimacy, which, once based on the exercise of voting rights, is now founded on impartiality and detachment from interests. The judiciary in particular has taken on this central role both in consolidated democracies and in those undergoing the consolidation process.

\section{Judiciary, Perceptions on Justice and (dis)trust in Institutions}

The emergence of counter-democracy, as Rosanvallon pointed out, removed from the Judiciary Power its bouche de la loi characteristic, as constructed in the Liberal State, and transformed it into an institution with political contours, especially in the constitutional 
courts. In contemporary democracies, the Judiciary is configured as an institution of power and its legitimacy derives from the competence of its actors to resolve social conflicts. This competence is founded on the intellectual and moral reputation derived from a supposedly impartial decision making process (Rosanvallon, 2006: 262).

Since the 1990s, the concept of judicialization of politics has been employed to describe processes by which the Judiciary Power has intervened in public policies implemented by democratic governments as well as in the legislative process. Therefore, courts - especially the Constitutional Courts - came to be seen as institutions that are essentially political, in large part due to the profound effects their decisions may exert on public policies, majoritarian preferences, and social values. Tate and Vallinder (1997) deal with the causes behind the expansion of the Judiciary Power and conceptualize judicialization of politics as a twofold process which involves: (1) broadening of decision power in the judicial system to create and execute laws and (2) the adoption, by other powers, of procedures typical of the judicial logic such as the Parliamentary Inquiry Commission (CPIs) by the Legislative, and administrative courts or judges by the Executive (Tate, 1997).

According to Neal Tate (1997), the judicialization of politics results from the process of political development, especially the consolidation of democracy. Therefore, democracy becomes a condition for judicialization insofar as the Judiciary Power, in order to intervene in public policies, depends on the existence of accountability institutions and control of the power of the majority regarding fundamental rights. Likewise, the separation of powers is also a condition for judicialization since functional autonomy is essential to the Judiciary. Third, the judicialization of politics stems from a politics of rights in which minorities can appeal to the due legal process to protect themselves from the majorities.

Associated to these three factors, Tate lists five more factors that derive from the use of the Judiciary in accordance to specific interests. Firstly, the judicialization of politics stems from the use of the courts by interest groups. Human rights defense groups, social movements, and corporative groups seek the courts in order to consolidate their interests in function of procedural and normative reasons expressed by Law. Second, judicialization stems from the use of courts by oppositions, aiming for the possibility of controlling governments. Third, judicialization stems from the ineffectiveness of majoritarian institutions in the exercise of government and legislative process. The weakening of these majoritarian institutions strengthens power delegation to the Judiciary. Fourth, judicialization stems from the public opinion's perception of the construction of public policies. A solidified perception of corruption or the distance from majoritarian citizens' interests begets a position in which the Judiciary is presented as a normative and moral resource grounded on legality and legitimacy. Finally, and less common according to Tate, judicialization stems from a 
delegation process by the very majoritarian institutions, which find themselves unable to govern or to legislate (Tate, 1997: 28-33).

Democracy consolidation leads to a process by which the Judiciary Power ascends in the public sphere by means of institutional changes that carry with them the centrality of the rule of law (Carvalho, 2007). On the other hand, it's important to observe that these institutional changes lead to transformations for the public opinion and in the composition of political culture.

By means of this process, counter-democracy institutions are drawn near to political representation. For John Hart Ely (1980), the presence of the Judiciary Power as an institution of representation is part of the very notion of democracy. As an institution whose legitimacy does not stem from majoritarian processes, but from a procedural conception of law, the Judiciary - especially the Constitutional Courts - emerges as a corrective for political representation. Hence, according to Ely, the presence of the Judiciary in the political process is not contradictory to the values of representational democracy. On the contrary, judicial control fosters social change and guarantees that the principle of equality is established.

The presence of the Judiciary allows for minorities to be represented against the abuses of the majority and ensures that representation does not promote distortions that could detriment fundamental rights. For Ely, distrust is not about the result of public policies implemented by governments, but a function of the procedures adopted for the decision-making process that occurs in the spheres of the Executive and Legislative Powers. In this sense, distrust depends on the observation of inequalities in the application of norms and rules (Ely, 1980). Hence, Ely's notion of distrust evokes that the empowerment of the Judicial Power in democracies depends on a negative perception of procedural equality as practiced by majoritarian representative institutions.

Therefore, such perspectives on judicialization do not conceive it as external to the changes in values and attitudes in democracies. Instead, this is a process that has its origins in the very strengthening of democracy (Rosanvallon, 2006), which in turn is associated to democratic political culture itself, along with new instruments for social mobilization, the internet and improvements in transparency instruments.

However, this literature does not take into account the particularities in young democracies in which the citizens' critical stand still coexists with ambivalent positions towards the normative values of democracy. Likewise, one cannot attribute judicialization in young democracies to a consolidated democratic trajectory insofar as a widespread perception of inequality remains, especially regarding the fundamental procedures of political and juridical decision. And lastly, it should be said that this process does not happen 
uniformly in all democracies, inasmuch as in young democracies it stems from institutional changes that derive from transition processes. The next section aims to analyze the Brazilian case.

\section{The Transformation of the Brazilian Judiciary and its Position in the Public Opinion}

When analyzing the Brazilian case, Werneck Vianna et al. (2007) calls attention to the fact that judges and courts have, since the 1970s, increasingly occupied roles that were traditionally reserved to political institutions. This occurs due to profound transformations whose origins date back to the second post-war period, especially with the introduction of a "dogmatic nucleus" to express fundamental values so as to compel the sovereign power in constitutional articles. This increasing regulation through Law would result in an open, unspecified and programmatic legislation, making juridical interpretation a fundamental point in democratic life (Werneck Vianna et al., 2007).

Just as in the preambles and declarations of fundamental rights of many post-war constitutions, normative principles of absolute legitimacy were also imposed to those that followed authoritarian regimes - such as in Brazil - as a mandatory source of limitation of the State and for all positive law. Therefore, the experience of democratic constitutionalism was generalized in Brazil as public law would then internalize a conception of social justice. The incorporation of justice ideals by modern constitutionalism served a symbolic role, producing information for the political system and legitimizing - by elucidating the fundamentals of juridical order - values, expectations, and behavior. That is to say, social justice would express the normative resources of political institutions and would ensure a process of citizenship promotion that refers to a prospection of positive liberty and equality as expressed in the 1988 Magna Carta. The constitutional acknowledgment of the demand for the implementation of foundational and social rights, originating from its prospective nature, legitimized the de-neutralization of the Judicial Power's function in Brazil, whose job is to examine whether the exercise of the power to legislate leads to the concretization of expected results as expressed in constitutional norms (Ferraz, 2007).

In Brazil, the 1988 Constitution displaced a juridical culture characterized by a kind of positivism with a privatizing disposition. This shift in juridical culture gave rise to an expansion in the conception of fundamental rights, understood as an assertion of principles. These principles, as expressed in article 5 of the 1988 Constitution, establish action programs and specify objectives to implicate the State's duty to action. The effectuation of fundamental rights is authored by a circle of interpreters within the judicial sphere. These interpreters put such rights into effect by means of an extensive hermeneutic process in 
which the aim is to give "density and embodiment to abstractly configured principles within the Constitution" (Cittadino, 2000: 39). The Judiciary in Brazil, conceived as this new public space, widened the exercise of a "complex sovereignty" where it combines political with functional representation. This combination occurs from two dimensions in the defense of citizenship: political - carried out by the elected representatives based on democratic procedures - and functional - carried out by the community of Law interpreters, made up of judicial agents legitimized by the Constitution (Werneck Viana et al., 2007).

In this sense, the Judiciary assumed the role of a vigilant for political institutions, considering that it provides the concreteness of social justice in public policies and the regularity of procedures and democratic values. Institutions in the judicial system present themselves as representatives of social interest and act in accordance to a growing criticism and dissatisfaction with democracy. Once majoritarian institutions show themselves to be unable to accomplish justice, thus nourishing the citizens' critical stand and distrust in institutions, institutional changes in the judicial system interact with the background political culture, reinforcing the judicialization of politics. Changes within the judicial system and the support towards the Judiciary's political agency arise in Brazil at the same time as distrust towards the political system's majoritarian institutions expands. In the Brazilian case, distrust towards institutions is due to a poor functioning of the political system regarding the society's interests, the constant presence of corruption by means of political scandals and the perception of their ineffectiveness when dealing with rights (Moisés and Carneiro, 2008).

Consequently, judicialization should not be understood merely as a process of institutional innovation derived from the centrality of rights, but as a process of decentering of democratic legitimacy, as Rosanvallon (2006) points out. In Brazil, the citizens' discontent with representative and electoral institutions would entail the displacement of democratic legitimacy towards the Judiciary. Therefore, judicialization cannot be understood solely by the actions of the judiciary, but also by an incisive agency by counter-majoritarian institutions such as the Public Ministry, who presents itself as an interpreter of Law and controller of the State's actions. In Brazil, following in the trails of Rosanvallon (2006), due to the presence of distrust towards political institutions and the presence of judicial system institutions in the public scene, a counter-democracy process emerged. Therefore, the changes within the Judiciary would not merely consist of a set of institutional innovations, but also of a displacement of the center of democratic political legitimacy, going from electoral representation towards juridical activism - the actions of the Judiciary, Public Minister and mobilization by part of the Constitution interpreters' community. This process constitutes in an interaction between institutional changes and political culture that modifies the scene for democratic institutions. 
If the specialized literatures highlights how judicialization occurs in consolidated democracies, this process holds certain particularities in countries ongoing a democratic consolidation process, especially when dealing with the perceptions on justice. In the case of Brazil the judicialization of politics, alongside the presence of distrust, does not imply in a perception by society of impartiality and equalitarian treatment in judicial procedures. As we see it, the Brazilian Judiciary was not empowered by means of a generalized distrust towards representative institutions. Just as it occurs with the representative institutions, the Brazilian Judiciary is immersed in the distrust syndrome insofar as in the light of public opinion it cannot ensure an equalitarian application of procedures and democratic values. Additionally, the perception of durable inequalities in Brazil does not allow for us to affirm that judicialization should be understood as a delegation of powers to the Judiciary, in the sense of an emergence of counter-democracy, according to Rosanvallon's argument (2006).

In the case of young democracies, such as Brazil, the perception of procedural inequality places the Judicial Power within the distrust syndrome, in spite of the endorsement of the normative values of democracy. The Brazilian Judiciary, by hypothesis, does not contribute to the correction of the vices in political representation, as Ely (1980) would affirm, but in fact it strengthens the dissatisfaction with democracy, considering it's part of the distrust syndrome. In order to test this hypothesis, the next section deals with data obtained by a survey in the metropolitan regions of Belo Horizonte, Goiânia, Recife and Porto Alegre.

\section{Methodology and Data Analysis}

A public opinion survey was carried out in the metropolitan regions of Belo Horizonte, Goiânia, Porto Alegre and Recife from a sample made up of 300 household interviews for each of the metropolitan regions, for a total of 1201 interviews. The sample was weighed - in its totality - by quotas concerning income range, gender, education level, age range and whether the respondent was part of the economically active population according to the 2010 Census $^{2}$.

The objective was to assess the impact of the Judiciary's agency in the satisfaction with democracy. The questions regarding the Judicial Power aimed to examine how respondents saw their role in the Brazilian political system as well as to examine fundamental issues related to procedures and institutional rules and, ultimately, its effects on democracy.

Firstly, the respondent was asked about his satisfaction with democracy in Brazil. Results show that dissatisfaction with democracy prevails for more than half of the sample, expressing therefore a critical context towards the regime. In the sample, 1.9\% of the 
respondents claim to be very satisfied, $38.2 \%$ claim to be satisfied, $51.3 \%$ claim to be dissatisfied and, lastly, $8.6 \%$ claim to be very dissatisfied. Similar results were found in the 2010 Latin Barometer for Brazil. For the Latin Barometer research, 3.4\% demonstrated to be very satisfied, $48.7 \%$ were satisfied, $33.6 \%$ were dissatisfied and $14.3 \%$ were very dissatisfied. Such results points to a relative dissatisfaction with democracy in Brazil, and so they reveal the emergence of citizens' criticism, conducted by the belief that democracy displays problems that could affect its legitimacy.

With the intent of verifying if dissatisfaction with democracy contrasts with adhesion to democratic values, a normative question was asked aiming to understand the concordance of individuals towards democracy, when compared to authoritarian governments. Results show that adherence to democracy is a majoritarian option in the sample, converging with other researches, including the Latin Barometer, which shows that regime dissatisfaction does not imply normative indifference for the individuals when comparing democracy and authoritarianism. Within the context of the sample, 50.3\% of the respondents answered "democracy is better than any other form of government", $22.0 \%$ of the sample answered "in some occasions an authoritarian government can be better than a democratic one" and lastly, 27.7\% of the sample answered "there is no difference between an authoritarian government and a democratic government". That is, in spite of the high dissatisfaction level, individuals adhere to the values of democracy. However, it is important to note that the data presents elevated indicators of ambivalence towards democracy in that $27.7 \%$ of the sample claim there is no difference between an authoritarian government and a democratic government, as well as a high indicator of the presence of an authoritarian option as expressed in the assertion that in some occasions an authoritarian government can be better than a democratic one.

By crossing the data presented above, one realizes that individuals who normatively endorse democracy have a higher tendency towards satisfaction with democracy. However, individuals who support the perspective of an authoritarian government tend to be dissatisfied with democracy. According to the data shown in table 1, it is possible to claim that satisfaction with democracy is associated with the normative endorsement of the democratic regime and that dissatisfaction with democracy is associated with the opinion of individuals who assume an ambivalent position towards democracy. 
Table 1. Satisfaction with democracy in Brazil x support for democracy

\begin{tabular}{|c|c|c|c|c|c|}
\hline \multirow[b]{2}{*}{ Support for democracy } & \multicolumn{5}{|c|}{ Satisfaction with democracy } \\
\hline & Very satisfied & Satisfied & Dissatisfied & $\begin{array}{c}\text { Very } \\
\text { dissatisfied }\end{array}$ & Total \\
\hline $\begin{array}{l}\text { Democracy is better than any other } \\
\text { form of government }\end{array}$ & $2,3 \%$ & $50,7 \%$ & $40,5 \%$ & $6,5 \%$ & $100 \%$ \\
\hline $\begin{array}{l}\text { In some occasions an authoritarian } \\
\text { government can be better than a } \\
\text { democratic one }\end{array}$ & $0,4 \%$ & $32,9 \%$ & $60,6 \%$ & $6,0 \%$ & $100 \%$ \\
\hline $\begin{array}{c}\text { There is no difference between an } \\
\text { authoritarian government and a } \\
\text { democratic government }\end{array}$ & $1,0 \%$ & $21,0 \%$ & $63,5 \%$ & $14,5 \%$ & $100 \%$ \\
\hline
\end{tabular}

Source: Centro de Referência do Interesse Público (Public Interest Reference Center), 2012.

Note: Pearson Chi-Square: 97,156 , significant to $95 \%$.

Respondents were also asked about their trust from a list of institutions. The objective is to observe how trust in institutions has an impact on satisfaction with democracy and test the two theoretical positions previously shown -- whether distrust has a negative impact on democratic legitimacy (Dalton, 1999; 2004) or if distrust can be a sign of vigor for democracy inasmuch as citizens vindicate for changes in the performance of institutions (Norris, 2011).

Table 2 below shows the trust and distrust frame regarding some specific institutions. We can observe that that data on table 2 converges with researches conducted by Moisés and Carneiro (2008) and Ribeiro (2011) in which the National Congress assumes the first position of distrust when compared to other institutions. It also reveals one data that points towards the tendency of assigning the Federal Police as a paladin for a favorable public opinion since its trust levels surpass 50\% (Arantes, 2011).

Table 2. Trust in institutions

\begin{tabular}{ccccc}
\hline \multirow{2}{*}{ Institutions } & Categories & Frequency & Percentage & $\begin{array}{c}\text { Valid } \\
\text { percentage }\end{array}$ \\
\hline \multirow{2}{*}{ Presidency of the Republic } & Trusts highly & 71 & 5,9 & 5,9 \\
\cline { 2 - 5 } & Trusts & 574 & 47,8 & 48,1 \\
\cline { 2 - 5 } & Distrusts & 449 & 37,4 & 37,6 \\
\cline { 2 - 5 } & Distrusts highly & 100 & 8,3 & 8,4 \\
\cline { 2 - 5 } & DNK/DNR & 7 & 0,6 & 100 \\
\hline
\end{tabular}




\begin{tabular}{|c|c|c|c|c|}
\hline \multirow{6}{*}{ National Congress } & Trusts highly & 27 & 2,2 & 2,3 \\
\hline & Trusts & 246 & 20,5 & 20,9 \\
\hline & Distrusts & 661 & 55,0 & 56,2 \\
\hline & Distrusts highly & 242 & 20,1 & 20,6 \\
\hline & DNK/DNR & 25 & 2,1 & -- \\
\hline & Total & 1201 & 100 & 100 \\
\hline \multirow{6}{*}{ Military police } & Trusts highly & 38 & 3,2 & 3,2 \\
\hline & Trusts & 447 & 37,2 & 37,6 \\
\hline & Distrusts & 538 & 44,8 & 45,2 \\
\hline & Distrusts highly & 166 & 13,8 & 14,0 \\
\hline & DNK/DNR & 12 & 1,0 & -- \\
\hline & Total & 1201 & 100 & 100 \\
\hline \multirow{6}{*}{ Civil Police } & Trusts highly & 38 & 3,2 & 3,2 \\
\hline & Trusts & 470 & 39,1 & 39,6 \\
\hline & Distrusts & 518 & 43,1 & 43,7 \\
\hline & Distrusts highly & 160 & 13,3 & 13,5 \\
\hline & DNK/DNR & 15 & 1,2 & -- \\
\hline & Total & 1201 & 100 & 100 \\
\hline \multirow{6}{*}{ Public Ministry } & Trusts highly & 58 & 4,8 & 4,9 \\
\hline & Trusts & 547 & 45,5 & 46,2 \\
\hline & Distrusts & 476 & 39,6 & 40,2 \\
\hline & Distrusts highly & 102 & 8,5 & 8,6 \\
\hline & DNK/DNR & 18 & 1,5 & -- \\
\hline & Total & 1201 & 100 & 100 \\
\hline \multirow{6}{*}{ Judicial Power } & Trusts highly & 45 & 3,7 & 3,8 \\
\hline & Trusts & 541 & 45,0 & 46,2 \\
\hline & Distrusts & 504 & 42,0 & 43,1 \\
\hline & Distrusts highly & 80 & 6,7 & 6,8 \\
\hline & DNK/DNR & 31 & 2,6 & -- \\
\hline & Total & 1201 & 100 & 100 \\
\hline \multirow{6}{*}{ Federal Police } & Trusts highly & 113 & 9,3 & 9,5 \\
\hline & Trusts & 669 & 55,7 & 56,5 \\
\hline & Distrusts & 317 & 26,4 & 26,8 \\
\hline & Distrusts highly & 86 & 7,2 & 7,3 \\
\hline & DNK/DNR & 17 & 1,4 & -- \\
\hline & Total & 1201 & 100 & 100 \\
\hline
\end{tabular}

Source: Centro de Referência do Interesse Público (Public Interest Reference Center), 2012. 
Distrust in institutions in Brazil is expressed to the point that, according to Moisés and Carneiro (2008), trust in institutions does not surpass 35\%, according to surveys carried out between 1995 and 2002. There is a generalized discontent in Brazil with parliaments, parties, government, courts of justice, the police, and health and education services (Ribeiro, 2011). The most important thing to notice is that such distrust is generalized insofar as this perception crosses segments of gender, income, education level, age and geographical distribution (Meneguello, 2007).

The survey also addressed the capacity of the institutions to produce justice. Since the survey deals with the Judiciary and its relations with political institutions, the respondents were asked to position themselves in regards to the capacity of institutions to produce justice, in a broad sense. This procedure was done to compare if the distrust expressed in the table above could be related to the capacity to produce justice. Questions were made regarding the capacity of the Judicial Power, government, National Congress, NGOs and associations, churches, and schools and universities to produce justice. The question did not specify what type of justice, merely its relation with the listed institutions. The data in table 3 below shows that institutions of a State character, the Judiciary, the government and National Congress have, in the opinions of the individuals, promoted less justice than institutions of a non-State character, that is, NGOs, churches, and schools and universities.

Table 3. Capacity of institutions to promote justice

\begin{tabular}{|c|c|c|c|c|}
\hline Institutions & Categories & Frequency & Percentage & Valid Percentage \\
\hline \multirow{6}{*}{ Judicial Power } & Promotes highly & 56 & 4,7 & 4,8 \\
\hline & Promotes & 451 & 37,6 & 38,4 \\
\hline & Promotes poorly & 515 & 42,9 & 43,8 \\
\hline & Does not promote & 153 & 12,7 & 13,0 \\
\hline & DNK/DNR & 26 & 2,2 & -- \\
\hline & Total & 1201 & 100 & 100 \\
\hline \multirow{6}{*}{ Government } & Promotes highly & 40 & 3,3 & 3,4 \\
\hline & Promotes & 383 & 31,9 & 32,4 \\
\hline & Promotes poorly & 565 & 47,0 & 47,8 \\
\hline & Does not promote & 193 & 16,1 & 16,3 \\
\hline & DNK/DNR & 20 & 1,7 & -- \\
\hline & Total & 1201 & 100 & 100 \\
\hline
\end{tabular}




\begin{tabular}{|c|c|c|c|c|}
\hline \multirow{6}{*}{ National Congress } & Promotes highly & 41 & 3,4 & 3,5 \\
\hline & Promotes & 278 & 23,1 & 23,8 \\
\hline & Promotes poorly & 510 & 42,5 & 43,7 \\
\hline & Does not promote & 337 & 28,1 & 28,9 \\
\hline & DNK/DNR & 35 & 2,9 & -- \\
\hline & Total & 1201 & 100 & 100 \\
\hline \multirow{6}{*}{ NGOs and associations } & Promotes highly & 76 & 6,3 & 6,6 \\
\hline & Promotes & 522 & 43,5 & 45,7 \\
\hline & Promotes poorly & 390 & 32,5 & 34,1 \\
\hline & Does not promote & 155 & 12,9 & 13,6 \\
\hline & DNK/DNR & 58 & 4,8 & -- \\
\hline & Total & 1201 & 100 & 100 \\
\hline \multirow{6}{*}{ Church } & Promotes highly & 95 & 7,9 & 8,0 \\
\hline & Promotes & 573 & 47,7 & 58,5 \\
\hline & Promotes poorly & 351 & 29,2 & 29,7 \\
\hline & Does not promote & 162 & 13,5 & 13,7 \\
\hline & DNK/DNR & 20 & 1,7 & -- \\
\hline & Total & 1201 & 100 & 100 \\
\hline \multirow{6}{*}{$\begin{array}{l}\text { Schools and } \\
\text { Universities }\end{array}$} & Promotes highly & 123 & 10,2 & 10,5 \\
\hline & Promotes & 647 & 53,9 & 55,2 \\
\hline & Promotes poorly & 279 & 23,2 & 23,8 \\
\hline & Does not promote & 124 & 10,3 & 10,6 \\
\hline & DNK/DNR & 28 & 2,3 & -- \\
\hline & Total & 1201 & 100 & 100 \\
\hline
\end{tabular}

Source: Centro de Referência do Interesse Público (Public Interest Reference Center), 2012.

The question regarding the capacity of institutions to promote justice does not allow for a clear crossing in relation to trust or distrust towards institutions. But it is possible to discern that both questions may be correlated insofar as they touch on central themes for the building of trust. We could very likely affirm that institutions incapable of producing justice are subjected to a larger distrust insofar that justice is a fundamental social aspiration.

The agency of the Judiciary must take into consideration the respect for equality, as previously pointed out in Ely's argument (1980). The relationship between justice and democracy should be measured by the capacity of judicial institutions to ensure internal procedures by which it is possible to establish, in an effective manner, procedural equality for citizens in regards to justice (Dworkin, 2001). As for the perceptions of individuals regarding equal treatment under the law, the most common answer was "no" for $61.4 \%$ of 
the respondents, followed by the answer "sometimes" for $21.8 \%$ of the sample and finally, the answer "yes" for $16.9 \%$ of the sample.

However, we must take into account that the Judiciary is not the only institution responsible for procedural equality within a democracy. For research purposes we confronted this data with a specific question regarding the Judiciary Power, interrogating whether it makes its decisions with no outside influence from politicians, businesspeople and other interest types. The most common answer in the sample, for $48.3 \%$ of the respondents, was "no", followed by the answer "yes" for $26.7 \%$ for the respondents, and the answer "sometimes" for $25.0 \%$ of the respondents.

This measurement of the Judiciary's impartiality means that its agency impacts citizens' perceptions on procedural equality. That is, once its agency is not oblivious to the interests of politicians, businesspeople or other interests, this perception impacts procedural equality as a fundamental republican value. The Brazilian Judiciary does not guarantee, in the opinion of the respondents, procedural equality, and therefore it is not recognized as an institution in which impartiality ensures its legitimacy under the Rule of Law. The crossing of data presented above allows us to verify a strong association among the two variables, according to table 4 below:

Table 4. Crossing Do laws consider all citizens equally? X The Judiciary takes its decisions without being influenced by politicians, businesspeople or other interests?

\begin{tabular}{cccccc}
\hline & \multicolumn{3}{c}{ Do laws consider all citizens equally? } \\
\hline & & Yes & Sometimes & No & Total \\
\hline \multirow{2}{*}{$\begin{array}{c}\text { Does the Judiciary make its decisions } \\
\text { without being influenced by politicians, } \\
\text { businesspeople or other interests? }\end{array}$} & Yes & $22.0 \%$ & $15.1 \%$ & $62.9 \%$ & $100 \%$ \\
\cline { 2 - 6 } & Sometimes & $12.7 \%$ & $41.7 \%$ & $45.6 \%$ & $100 \%$ \\
\cline { 2 - 6 } & No & $15.4 \%$ & $14.6 \%$ & $70 \%$ & $100 \%$ \\
\hline
\end{tabular}

Source: Centro de Referência do Interesse Público (Public Interest Reference Center), 2012. Note: Pearson Chi-Square: 95,901, significant to $95 \%$.

As a hypothesis, insofar as the Judiciary is not seen as ensuring procedural equality in its decision-making process - as indicated in the data sample - we can speculate that such perception is influenced by a relative deprivation of basic public goods. That is, the feeling of dissatisfaction towards the offer of public goods and the perception of one's own life may have an impact on the satisfaction with democracy and contaminate the perception of the Judiciary itself. To this end, the research employed a relative deprivation indicator based on questions regarding peoples' satisfaction with basic issues that impact their personal life (Vala and Marinho, 2003), asking questions about subjective evaluation of distributive justice, especially those related to the personal conditions on safety, health, 
education and housing, and a question on personal life satisfaction. The data in table 5 below reveals higher dissatisfaction rates regarding safety and health than regarding education and housing. In spite of the dissatisfaction with the offer of basic public goods, the respondents reveal a high satisfaction rate with their personal life.

Table 5. Perception of relative deprivation

\begin{tabular}{|c|c|c|c|c|}
\hline & Categories & Frequency & Percentage & Valid percentage \\
\hline \multirow{6}{*}{ Personal and family safety } & Very satisfied & 28 & 2,3 & 2,3 \\
\hline & Satisfied & 391 & 32,6 & 32,6 \\
\hline & Dissatisfied & 656 & 54,6 & 54,7 \\
\hline & Very Dissatisfied & 125 & 10,4 & 10,4 \\
\hline & DNK/DNR & 1 & 0,1 & -- \\
\hline & Total & 1201 & 100 & 100 \\
\hline \multirow{6}{*}{$\begin{array}{l}\text { Your children's or similar } \\
\text { education }\end{array}$} & Very satisfied & 55 & 4,6 & 4,6 \\
\hline & Satisfied & 661 & 55,0 & 55,3 \\
\hline & Dissatisfied & 426 & 35,5 & 35,6 \\
\hline & Very Dissatisfied & 54 & 4,5 & 4,5 \\
\hline & DNK/DNR & 5 & 0,4 & -- \\
\hline & Total & 1201 & 100 & 100 \\
\hline \multirow{6}{*}{ Personal and family health } & Very satisfied & 52 & 4,3 & 4,3 \\
\hline & Satisfied & 558 & 46,5 & 46,5 \\
\hline & Dissatisfied & 479 & 39,9 & 39,9 \\
\hline & Very Dissatisfied & 111 & 9,2 & 9,3 \\
\hline & DNK/DNR & 1 & 0,1 & -- \\
\hline & Total & 1201 & 100 & 100 \\
\hline \multirow{6}{*}{ Housing conditions } & Very satisfied & 97 & 8,1 & 8,1 \\
\hline & Satisfied & 804 & 66,9 & 66,9 \\
\hline & Dissatisfied & 261 & 21,7 & 21,7 \\
\hline & Very Dissatisfied & 39 & 3,2 & 3,2 \\
\hline & DNK/DNR & 0 & 0 & -- \\
\hline & Total & 1201 & 100 & 100 \\
\hline \multirow{6}{*}{ Your personal life } & Very satisfied & 167 & 13,9 & 14,0 \\
\hline & Satisfied & 902 & 75,1 & 75,4 \\
\hline & Dissatisfied & 118 & 9,8 & 9,9 \\
\hline & Very Dissatisfied & 10 & 0,8 & 0,8 \\
\hline & DNK/DNR & 4 & 0,3 & -- \\
\hline & Total & 1201 & 100 & 100 \\
\hline
\end{tabular}

Source: Centro de Referência do Interesse Público (Public Interest Reference Center), 2012. 
We speculated if the dissatisfaction with democracy could be related to the performance of the judicial institutions. A measure was established asking the respondents if the performance of institutions in the judicial system was excellent, good, average, bad or awful. According to data on table 6, the highest criticism revolves around access to the Judiciary Power and the performance of the Public Defender.

Table 6. Evaluation of the performance of judicial institutions

\begin{tabular}{cccccc}
\hline \multirow{2}{*}{ Institutions } & \multicolumn{3}{c}{ Categories } \\
\cline { 2 - 6 } & Excellent & Good & Average & Bad & Awful \\
\hline Performance of judges of Law & $11,8 \%$ & $43,5 \%$ & $29,3 \%$ & $7,2 \%$ & $8,2 \%$ \\
\hline Access to Judicial Power & $8,0 \%$ & $39,8 \%$ & $30,1 \%$ & $12,8 \%$ & $9,4 \%$ \\
\hline Performance of lawyers & $8,3 \%$ & $43,7 \%$ & $30,3 \%$ & $10,0 \%$ & $7,8 \%$ \\
\hline Performance of public prosecutors & $10,7 \%$ & $46,8 \%$ & $30,1 \%$ & $5,5 \%$ & $7,0 \%$ \\
\hline Performance of the Public Defender & $8,8 \%$ & $42,2 \%$ & $30,1 \%$ & $9,3 \%$ & $9,6 \%$ \\
\hline Performance of the Special Courts & $9,8 \%$ & $47,9 \%$ & $28,4 \%$ & $6,2 \%$ & $7,7 \%$ \\
\hline
\end{tabular}

Source: Centro de Referência do Interesse Público (Public Interest Reference Center), 2012.

Lastly, we questioned the respondents on their knowledge of the articles in the 1988 Federal Constitution. The large majority of respondents said they did not know the Magna Carta: $78.6 \%$ of the respondents revealed they did not know the articles in the 1988 Federal Constitutions, followed by those respondents who claimed to know a few, represented by $12.2 \%$ of the sample and, lastly, 9.2\% of the respondents who claimed knowledge of the Constitution's articles. This variable offers a cognitive measurement regarding Law and fundamental rights.

Taking this set of data into consideration, we seek to establish their dimensionality by means of a factor analysis through the extraction of main components. The factor analysis allows us to comprehend the data interaction and how they aggregate and correlate with hypothetical factors. The objective of this technique is to establish the dimension of the data, identifying the latent factors that represent the interactions within the set of variables. We sought to define the factors associated with the respondents' answers regarding the Judiciary and trust in institutions. Before we proceed to the factor analysis we tested data reliability in order to investigate if they discriminate the set of informers by means of a Cronbach's alpha index. By aggregating the variables that will be exposed in the factor model we reached a 0.859 index, which allows us to validate the factor model composition. The factor model served to verify the aggregation effect in variables related to different forms of perceiving the performance of the judicial system regarding the themes of trust and procedural equality. By gathering the data presented above, table 7 below presents the matrix for main component and factor loads. 
Table 7. Matrix of main component and factor loads

\begin{tabular}{|c|c|c|c|c|c|c|c|}
\hline Variables & Factor 1 & Factor 2 & Factor 3 & Factor 4 & Factor 5 & Factor 6 & Factor 7 \\
\hline Trust in the Presidency of the Republic & ,461 & & & & & & \\
\hline Trust in the National Congress & ,353 &, 578 & & & & & \\
\hline Trust in the Military Police & ,793 & & & & & & \\
\hline Trust in the Civil Police & ,788 & & & & & & \\
\hline Trust in the Public Ministry & ,686 & & & & & & \\
\hline Trust in the Judicial Power & ,601 & & & & & & \\
\hline Trust in the Federal Police &, 722 & & & & & & \\
\hline Judicial Power's ability to produce justice & &, 627 & & & & & \\
\hline Government's ability to produce justice & & ,816 & & & & & \\
\hline National Congress' ability to produce justice & &, 759 & & & & & \\
\hline $\begin{array}{l}\text { NGOs and associations' ability to produce } \\
\text { justice }\end{array}$ & & & ,694 & & & & \\
\hline Church's ability to produce justice & & &, 775 & & & & \\
\hline $\begin{array}{l}\text { Schools and universities' ability to produce } \\
\text { justice }\end{array}$ & & & ,775 & & & & \\
\hline Satisfaction with personal and family safety & & & &, 557 & & & \\
\hline $\begin{array}{c}\text { Satisfaction with your children's or similar } \\
\text { education }\end{array}$ & & & & ,712 & & & \\
\hline Satisfaction with personal and family health & & & & ,698 & & & \\
\hline Satisfaction with housing conditions & & & & ,670 & & & \\
\hline Satisfaction with your personal life & & & & ,657 & & & \\
\hline $\begin{array}{c}\text { Perception of the equality of application of } \\
\text { laws }\end{array}$ & & & & & ,714 & & \\
\hline $\begin{array}{l}\text { Perception of the influence of politicians } \\
\text { and other interest groups in the Judiciary's } \\
\text { decisions }\end{array}$ & & & & & ,697 & & \\
\hline $\begin{array}{c}\text { Do you know the articles of the } 1988 \\
\text { Constitutions? }\end{array}$ & & & & & & ,796 & \\
\hline $\begin{array}{l}\text { Evaluation on the performance of judges of } \\
\text { Law }\end{array}$ & & & & & & &, 794 \\
\hline Access to Judicial Power & & & & & & & ,790 \\
\hline Evaluation on the performance of lawyers & & & & & & & ,814 \\
\hline $\begin{array}{c}\text { Evaluation on the performance of public } \\
\text { prosecutors }\end{array}$ & & & & & & & ,826 \\
\hline $\begin{array}{c}\text { Evaluation on the performance of the Public } \\
\text { Defender }\end{array}$ & & & & & & &, 794 \\
\hline $\begin{array}{l}\text { Evaluation on the performance of the Special } \\
\text { Courts }\end{array}$ & & & & & & & ,818 \\
\hline
\end{tabular}

Extraction method: Analysis of main components.

Rotation Method: Varimax with Kaiser Normalization. Total variance explained: $62.97 \%$.

Measure of adequacy Kayser-Meyer-Olkin (KMO) : 0.851

Bartlett's test of sphericity: Chi-square approximate: 3218.108 - DF: 351 - Sig: .000

Source: Centro de Referência do Interesse Público (Public Interest Reference Center), 2012. 
We can observe in the factor matrix that the data aggregation allows us to affirm that there are seven dimensions or latent factors present in the analysis. The commonalities were tested and signified, reaching the value of 1 . The matrix above results from a Varimax rotation process with Kaiser Normalization, presenting a KMO validity measure of 0.851. The first factor aggregated data concerning trust in institutions. It is then possible to understand trust in institutions as a latent factor. It's interesting to observe that the perception of the National Congress diverged from the perception of other institutions, being strongly associated with the capacity to produce justice in the context of state institutions. The second factor stipulated by the model aggregates the capacity to produce justice by the Judicial Power, government, and National Congress as a latent dimension to be considered. It contrasts with the third factor, which differentiated the capacity to produce justice by NGOs, church, and schools and universities, as a distinct factor. Therefore, the second factor was considered as the capacity by state institutions to promote justice and the third factor as the capacity of non-state institutions to promote justice. The fourth latent factor in the model aggregated the respondents' perception regarding relative deprivation. The data of the variables associated to this factor present the same direction and sense. The fifth latent factor would be the perception of procedural equality as practiced by the Judiciary. As shown in table 4 above, the variables that take into account the perception of inequality in the application of laws, and the perception of the influence from politicians, businesspeople and other interests in the Judiciary have the same direction, representing a distinct factor for the analysis. The sixth factor isolated the variable concerning the respondents' knowledge on articles in the 1988 Constitution. This factor only presented this variable as an isolated element in the analysis. Lastly, the seventh factor aggregated variables concerning the respondents' perception on the performance of institutions and agents in the judicial system.

The factor analysis technique allows us to comprehend the interaction between variables and search for unobserved latent variables by means of the aggregation in the set of variables. Based on this factor model, we built a logistic regression model in order to understand how each one of these factors impact dissatisfaction with democracy. Firstly, we transform the variable on dissatisfaction with democracy in a binary variable, aggregating the categories "very satisfied" and "satisfied" in a single "satisfied" category. The categories "dissatisfied" and "very dissatisfied" were aggregated with the "dissatisfied" category. This logistic regression procedure allows us to comprehend the impact of factors derived from the factor analysis on dissatisfaction with democracy. Table 8 below presents the results for the conducted logistic regression and the impacts of the factors on dissatisfaction with democracy. That is, the model allows us to identify the impact of each one of these seven factors in the chance of respondents having answered that they are dissatisfied with 
democracy. The proposed logistic model was controlled by the variables: gender, whether the respondent belongs to the economically active population, low or high educational level, and income lower than or superior to $\mathrm{R} \$ 1,635$ (3 minimum wages). The model was run from the scores established in the above factor analysis.

Table 8. Logistic regression model Dependent variable: Dissatisfaction with democracy

\begin{tabular}{ccccccc}
\hline Variables & B & S.E. & Wald & Df & Sig. & Exp(B) \\
\hline Gender (male) &, 335 &, 270 & 1,545 & 1 &, 214 & 1,398 \\
\hline Economically active population (yes) &,- 250 &, 311 &, 646 & 1 &, 421 &, 779 \\
\hline Education (low) &,- 172 &, 506 &, 115 & 1 &, 734 &, 842 \\
\hline Income lower than R\$1635,00 &,- 215 &, 265 &, 662 & 1 &, 416 &, 806 \\
\hline Trust in institutions &, 310 &, 132 & 5,550 & 1 &, 018 & 1,364 \\
\hline Capacity to promote justice by part of State institutions &, 470 &, 132 & 12,787 & 1 &, 000 & 1,601 \\
\hline Capacity to promote justice by part of non-State institutions &,- 006 &, 128 &, 002 & 1 &, 962 &, 994 \\
\hline Perception of relative deprivation &, 627 &, 147 & 18,132 & 1 &, 000 & 1,872 \\
\hline Perception of procedural inequality performed by the &, 255 &, 126 & 4,075 & 1 &, 044 & 1,290 \\
\hline Judiciary &,- 142 &, 129 & 1,210 & 1 &, 271 &, 867 \\
\hline Evaluation of the performance of judicial institutions &, 086 &, 127 &, 460 & 1 &, 498 & 1,090 \\
\hline Constant &, 412 &, 247 & 2,787 & 1 &, 095 & 1,509
\end{tabular}

Dependent variable: Dissatisfaction with democracy - analysis category: dissatisfied

Source: Centro de Referência do Interesse Público (Public Interest Reference Center), 2012.

By observing the table above, we see that some factors cannot be analyzed since they do not present a significance index lower than $5 \%$. This is the case of the variables: gender, economically active population, education, income lower than $\mathrm{R} \$ 1,635$, capacity to produce justice by non-State institutions, knowledge of the 1988 Constitution, and evaluation of the performance of judicial institutions. We therefore disregarded these variables.

As for the factor trust in institutions, distrust causes a 36\% increase in the chance of dissatisfaction with democracy in Brazil, being therefore a significant indicator. The impact of the factor ability to promote justice by State institutions causes a $60 \%$ increase in the chance of dissatisfaction with democracy. That is, the citizens' criticism concerning the State institutions' capacity to produce justice increases by $60 \%$ the chance of the respondents in the sample to answer that they are dissatisfied with democracy. On the other hand, the factor capacity to promote justice by non-State institutions does not impact dissatisfaction with democracy and is also not significant to the analysis. The perception of relative deprivation significantly impacts dissatisfaction with democracy, increasing the response to this item by $87 \%$. The perception of procedural inequality performed by 
the Judiciary significantly impacts dissatisfaction with democracy, increasing in $29 \%$ the chance of response to this item.

We conclude from the analyses that the factors with a higher impact on dissatisfaction with democracy are, respectively, the perception of relative deprivation, perception of the inability of State institutions to promote justice, distrust in institutions and, lastly, perception of the procedural inequality practiced by the Judiciary Power. Hence, we can observe that dissatisfaction with the democratic regime in Brazil is firstly motivated by a negative perception towards certain social justice indicators, and only then is it a problem of distrust in institutions. As we previously highlighted, it is not possible to directly compare the relation between social justice and trust. Nevertheless, it is possible to know that the perception of a lack of promotion of justice, which certainly elevates the perception of relative deprivation, has a bigger impact on dissatisfaction with democracy than the problem of distrust in institutions. Therefore, we can infer that the democratic deficit is associated with the perception of social justice in Brazil, within the context of an exclusionary society, pervaded by enormous inequalities. Within this context, the perception of the performance of the Judiciary is ambivalent insofar as it operates within the expectations of producing justice at the same time that this same Judiciary continues to reproduce strong procedural inequalities in light of its evaluation by public opinion. We therefore deduce that justice, and social justice in particular, is a problem of highest priority for Brazilian society and that it impacts democracy in a way that increases the dissatisfaction towards the regime. And, at the same time, the Judiciary is inserted in the citizens' criticism concerning the democratic deficit.

\section{Final Considerations}

The data analysis carried out above allows us to assert that perception of justice in Brazil holds certain particularities when compared to consolidated democracies. Firstly, the Brazilian Judiciary is immersed in the distrust syndrome, impeding us to affirm, as Ely (1980) and Rosanvallon (2006) do, that distrust empowers the Judiciary in order to intervene and to correct majoritarian political representation. This is confirmed by the fact that the perception of the workings of justice in Brazil does not attribute impartiality to the Judiciary in relation to political interests. Instead, there is a negative perception concerning the unequal agency of this institution, which in turn impacts dissatisfaction with democracy. Unlike consolidated democracies, we can attribute this fact to the permanence of a sentiment of relative deprivation, which persists due to the perpetuity of inequalities and the inefficiency of the Brazilian State to carry out equalitarian and equitable public 
policies. Functional representation is then immersed in the same societal distrust towards political institutions.

In this sense, the agency of the Judicial Power in Brazil can be understood as a result of the process of institutional changes carried out by the 1988 Constitution, but such agency should be regarded with caution when it comes to its relation to distrust, in the sense that it would give the judiciary institutions a prerogative to ensure minority representation and to strengthen vigilance in order to correct the improprieties of representative democracy. The distrust of institutions in Brazil does not empower the Judiciary, but places it within the citizenship criticism due to the permanence of perceived inequality in its regular operation. The negative perception of representative democracy also affects functional representation exerted by counter-democracy institutions. Therefore, the Judiciary is inserted within the democratic deficit criticism.

Democratic consolidation and the possible reversion of distrust in institutions in Brazil depend on a decrease in the intensity concerning the perception of inequalities. This is true both for the sentiment of relative deprivation towards access to fundamental public goods as well as in procedural equality, which should be practiced by political institutions as well as judicial institutions. Without strengthening institutions and ensuring the prevalence of the rule of law, it becomes impossible to establish a democratic political culture and to have citizens supporting and trusting the normative resources employed by institutions. This interaction between political culture and institutions demands further investigation in the Brazilian case, with special emphasis on the evaluation of institutions' normative resources and their role in producing justice and inequality-reduction.

Institutional changes derived from the judicialization of politics may result in an uncontrolled Judiciary Power in Brazil as well as in efforts to control representation as exerted in courts and which lack a public sense buoyed by the rule of law. Judicialization of politics may lead to new forms of authoritarianism in which the inherent depoliticization leads to populist temptations (Rosanvallon, 2006) or a new form of elitism disguised as a defense of democratic values, which merely maintains inequalities intact (Hirschl, 2004). As for the Brazilian case, the judicialization process seems to lead, due to the interaction between political culture and institution changes, to this second tendency, considering that the Judiciary's agency presents itself in an ambivalent position between the defense of democratic values and an elitism that reproduces social inequalities.

The propositions of this article must be tested in comparative researches of a broader scope as so to better understand the role of the Judiciary Power in young democracies. For the Brazilian case at least, it's important to perceive how distrust does not exempt the Judiciary from criticism and does not allow us to affirm that judicialization is its direct consequence. If there is something that amplifies the distrust in institutions and its 
ambivalent relationship towards satisfaction with democracy, it's certainly the perception of inequalities and their permanence in young democracies. If distrust results from the inability of institutions to mobilize their normative resources, then the permanence of inequalities - social injustice and the failure to comply with fundamental procedures to the rule of law - corrodes its ability to establish a democratic culture. If there is one thing that corrodes democracy, inequalities are a certain part of this process and how they lead to corruption, inefficiency of public policies and the ineffectiveness of the rule of law.

\section{Translated by Paulo Cesar Almeida Scarpa}

Submitted in August 2012

Accepted in July 2013

\section{References}

ARANTES, Rogério B. (2011), Polícia Federal e construção institucional. In: Corrupção e sistema político no Brasil, edited by Leonardo Avritzer and Fernando Filgueiras. Rio de Janeiro: Civilização Brasileira.

BRASIL. Constituição da República Federativa do Brasil. Brasília, DF: Senado Federal, 1988.

CARVALHO, Ernani. (2007), Revisão judicial e judicialização da política no direito ocidental: aspectos relevantes de sua gênese e desenvolvimento. Revista de Sociologia e Política, $\mathrm{n}^{\circ} 28$, pp. 161-179.

CITTADINO, Gisele. (2000), Pluralismo, direito e justiça distributiva - elementos da filosofia constitucional contemporânea. Rio de Janeiro: Lumen Juris.

DALTON, Russell. (1999), Political support in advanced industrial democracies. In: Critical citizens. Global support for democratic government, edited by Pippa Norris. Oxford: Oxford University Press.

DALTON, Russell. (2004), Democratic challenges, democratic choices. Oxford: Oxford University Press.

DWORKIN, Ronald. (2001), Uma questão de princípio. São Paulo: Martins Fontes.

ELY, John Hart. (1980), Democracy and distrust: a theory of judicial review. Harvard: Harvard University Press.

FERRAZ Jr., Tércio Sampaio. (2007), Direito Constitucional. Barueri: Manole.

FILGUEIRAS, Fernando. (2008), Corrupção, democracia e legitimidade. Belo Horizonte: Editora da UFMG.

FILGUEIRAS, Fernando. (2011), Transparência e controle da corrupção no Brasil. In: Corrupção e sistema político no Brasil, edited by Leonardo Avritzer and Fernando Filgueiras. Rio de Janeiro: Civilização Brasileira. 
HARDIN, Russell. (1999), Do we want trust in government? In: Democracy and trust, edited by Mark Warren. Cambridge: Cambridge University Press.

HIRSCHL, Ran. (2007), Towards juristocracy. The origins and consequences of the new constitutionalism. Cambridge: Harvard University Press.

INGLEHART, Ronald and WELZEL, Christian. (2005), Modernization, Cultural Change, and Democracy: the human development sequence. New York: Cambridge University Press.

KLINGEMANN, Hans-Dieter and FUCHS, Dieter. (ed.). (1995), Citizens and the state. Oxford: Oxford University Press.

LEVI, Margaret. (1998), A state of trust. In: Trust and Governance, edited by Valerie Braithwaite and Margaret Levi. New York: Russell Sage Foundation.

LUHMANN, Niklas. (1996), Confianza. Ciudad de México: Universidad Iberoamericana.

MENEGUELLO, Rachel. (2007), Grounds of democratic adherence: Brazil 2002-2006. Lanic Etext Collection, vol. 1, pp. 1-38.

MOISÉS, José Álvaro and CARNEIRO, Gabriela P. (2008), Democracia, desconfiança política e insatisfação com o regime: o caso do Brasil. Opinião Pública, vol. 14, nº 1, pp. 1-42.

NEWTON, Kenneth. (1999), The Impact of Social Trust on Political Support. In: Critical citizens. Global support for democratic government, edited by Pippa Norris. Oxford: Oxford University Press.

NORRIS, Pippa. (1999), Critical citizens: Global support for democratic government. Oxford: Oxford University Press.

NORRIS, Pippa. (2011), Democratic deficit. Critical citizens revisited. New York: Cambridge University Press.

OFFE, Claus. (1999), How can we trust our fellow citizens? In: Democracy and trust, edited by Mark Warren. Cambridge: Cambridge University Press.

PHARR, Susan J. and PUTNAM, Robert D. (2000), Disaffected Democracies: What's Troubling the Trilateral Countries? Princeton: Princeton University Press.

PUTNAM, Robert. (1993), Making Democracy Work: Civic Traditions in Modern Italy. Princeton: Princeton University Press.

RIBEIRO, Ednaldo A. (2011), Valores pós-materialistas e cultura política no Brasil. Maringá: EDUEM.

ROSANVALLON, Pierre. (2006), La contre-démocratie: la politique à l'âge de la défiance. Paris: Seuil.

SIMMEL, Georg. (1977), El secreto y la sociedad secreta. In: Sociologia: Estudios sobre las formas de socialización. Madrid: Biblioteca de la Revista Del Occidente.

TATE, Neal. (1997), Why the expansion of judicial power? In: The global expansion of judicial power, edited by Neal Tate and Tornjorrn Vallinder. New York: New York University Press. 
VALA, Jorge and MARINHO, Cristina. (2003), Percepções de justiça social, confiança e avaliação do sistema político. In: Desigualdades sociais e percepções de justiça, edited by Manuel Villaverde Cabral, Jorge Vala and André Freire. Lisboa: Imprensa de Ciências Sociais.

WERNECK VIANNA, Luiz; BURGOS, Marcelo B.; SALLES, Paula M. (2007), Dezessete anos de judicialização da política. Tempo Social, vol. 19, n² 2, pp. 39-85.

\section{Notes}

1 This article was presented at the VIII Meeting of the Brazilian Association of Political Science (Encontro da Associação Brasileira de Ciência Política) in 2012, in the city of Gramado, Rio Grande do Sul. I would like to thank the comments made by Julian Borba (UFSC) and Marcelo Baquero (UFRGS). I would also like to thank the comments made by Mário Fuks (UFMG) concerning the original version of this article. I also thank the anonymous peer reviewers from the Brazilian Political Science Review for their suggestions and considerations for the overall argument.

2 The data collection occurred between the $7^{\text {th }}$ and $12^{\text {th }}$ of January, 2012. The sample makes up for a confidence level of $95 \%$, with a margin of error estimated at $+/-4 \%$. 